\title{
DEREGULATION AND ENVIRONMENTAL DIFFERENTIATION IN THE ELECTRIC UTILITY INDUSTRY
}

\author{
MAGALI DELMAS, ${ }^{1 *}$ MICHAEL V. RUSSO ${ }^{2}$ and \\ MARIA J. MONTES-SANCHO ${ }^{3}$ \\ ${ }^{1}$ Donald Bren School of Environmental Science and Management, University of \\ California, Santa Barbara, California, U.S.A. \\ ${ }^{2}$ Lundquist College of Business, University of Oregon, Eugene, Oregon, U.S.A. \\ ${ }^{3}$ Department of Business Administration, University of Carlos III, Madrid, Spain
}

\begin{abstract}
This paper analyzes how economic deregulation impacts firm strategies and environmental quality in the electric utility industry. We find evidence that the deregulation introduced to this historically staid industry has stimulated environmental differentiation. Differentiation is most likely to appear where its point of uniqueness is valued by customers, and we confirm this relationship in our sample. Specifically, utilities that served customers who exhibited higher levels of environmental sensitivity generated more 'green' power. The tendency for firms to differentiate in this way is lessened if they are relatively more dependent on coal-fired generation or relatively more efficient. Thus, there is evidence that firms sort themselves into either differentiation or lowcost strategies as the competitive realities of a deregulated world unfold. Deregulation and the ensuing environmental differentiation illustrate how utilities exploited formerly unmet customer demand for green power. The result has been greater levels of renewable generation and, hence, a cleaner environment.
\end{abstract}

\section{INTRODUCTION}

Institutional change can advance the welfare of society. For example, properly designed public policies can augment the supply of public goods, like a healthy natural environment. Institutional change also has the potential to reshape the competitive landscape and lead to new strategic choices by firms. This was illustrated when firms created

Keywords: deregulation; environmental differentiation; electric utility; renewable energy; productive efficieny

* Correspondence to: Magali Delmas, Donald Bren School of Environmental Science and Management, University of California, Santa Barbara, CA 93106, U.S.A.

E-mail: delmas@bren.ucsb.edu a variety of strategies in reaction to regulatory reforms that promoted market instruments for reducing pollution. But how are institutional change, strategic choice, and the supply of public goods related? Studies that link all three of these factors are difficult to find.

We attempt to fill this important gap with a study of deregulation, differentiation, and the provision of 'green' power in the electric utility. We believe that under deregulation the familiar pattern of firms applying their resources to differential strategies will take place. For utilities, this process was stimulated by new freedoms that allowed them to view ratepayers not as an aggregate mass of demand but as an amalgam of distinct customer groups. 
Strategies they then developed reflected choices about serving these customer groups. To appreciate this and other examples of strategies driven by deregulation, we leverage the literature on institutional change and strategic choice. This permits us to fashion theories about how deregulation will elicit environmental differentiation as a function of firm and contextual variables.

We test hypotheses that follow from this theory development. We find evidence that deregulation triggered differentiation behavior by utilities, in the form of increased generation of 'green' power. Furthermore, this differentiation is accentuated in states where the populace displays greater levels of environmental sensitivity. Thus, the principles of effective differentiation have been applied in the industry. Together, these results expand our knowledge about using institutional change as a vehicle for broadening the provision of public goods. In this way, significant public policy implications flow from our results.

\section{Strategic response to deregulation}

A rich and diverse literature explores how economic regulation and deregulation have impacted the behavior of firms. Theories have been developed by drawing liberally from the literature in strategic management and organization theory. A common theme has been that institutional change redraws industry boundaries, shifts the scope of permissible activities for incumbents and entrants, and otherwise changes incentives for behavior (e.g., Bonardi, 2004; Delmas and Tokat, 2005; Fuentelsaz, Gomez, and Polo, 2002; Haveman, 1993; Haveman, Russo, and Meyer, 2001; Meyer, Brooks, and Goes, 1990; Miller and Chen, 1994; Smith and Grimm, 1987).

A number of studies have focused on the connection between institutional change and strategic choices made by organizations following deregulation. Before reviewing these, it is important to note that deregulation can take many forms. To name just a few, deregulation can permit new competitors to enter a field previously closed to them (e.g., airlines), it can allow incumbents to compete in fields previously closed to them (e.g., savings and loans), and it can remove restrictions on pricing (long-distance telecommunications). Frequently, deregulation combines some or all of these. The competitive implications of deregulatory regimes can vary greatly-one reason they have elicited very different reactions in affected industries.

Regulation can engender a strong family resemblance among the strategies pursued by affected firms. In large measure, this is due to the incentive structure faced by a regulated firm. Under regulation, these incentives can differ acutely from those at work in market competition. In fact, under some forms of economic regulation it actually can be in the interest of the firm to be, in Porter's (1985) phrase, 'stuck in the middle.' This peculiar outcome is due to the lack of incentives to innovate on any important dimension. Prior to deregulation, this situation arguably existed in the industry that we study here: electric utilities. Utilities were granted a guaranteed rate of return on traditional activities but were subject to some risk if they innovated, because regulators could rule costs associated with this activity imprudent if innovative efforts fail. So few utilities were willing to be first movers and companies tend to look very similar to one another.

Deregulation, by contrast, consistently stimulates processes of strategic choice. ${ }^{1}$ Smith and Grimm (1987) identified profound shifts in the strategies of railroads following deregulation. Haveman (1993) found that, once able to diversify, savings and loans expanded aggressively into new domains. Bonardi (1999) showed how customer segmentation followed regulatory relaxation in British telecommunications, with some firms targeting specific customer segments and others competing aggressively on price. Cho and Hambrick (2006) established that deregulation shifted managerial perspectives to a more entrepreneurial mindset. Russo (2001) found that new technological forms appeared in the utility industry following institutional change that facilitated entry.

Several studies have suggested that particular strategies can pay off under deregulation. Smith and Grimm (1987), studying railroads after deregulation, found that the differentiators outperformed others. Corsi et al. (1991) replicated the result in their study of the less-than-truckload trucking industry following deregulation. Haveman (1992) found that diversification by savings and loans

\footnotetext{
${ }^{1}$ Not all industries experienced short-term changes by incumbents. In the airline industry (Winston, 1998), incumbents were slow to embrace change following deregulation. Looking at the response of banks to the Community Reinvestment Act, Fox-Wolfgramm, Boal, and Hunt (1998) also found resistance to change.
} 
after their deregulation generally augmented profits, though the greatest gains were captured by firms that leveraged their existing competency base. In the context of the retail deregulation in the U.S. electric utility sector, Delmas and Tokat (2005) showed that firms that were vertically integrated into electricity generation or that relied on the market for the supply of their electricity were more efficient than firms that adopted hybrid structures combining vertical integration and contracting for power.

The strategic archetypes of differentiation and cost leadership have consistently materialized in industries undergoing deregulation. In airlines, the rise of the hub and spoke system meant that flyers were much more conveniently served by airlines that had the city nearest to them as a hub, because that airline could offer so many non-stop routes. Airlines with a given city for a hub thus were differentiated from airlines that would need to have passengers change planes in their own hubs en route to their destination. Schneider National, a long-time competitor in the truckload segment of long-distance trucking, responded to deregulation by launching a low-cost strategy that leveraged operating efficiencies created by heavy investment in logistics and communications infrastructure (Schneider National, 2005; Winston, 1998).

While the studies we have reviewed have collectively traced out an interesting body of literature in the area of institutional change and strategic choice, management researchers have tended to avoid the normative elements of these processes (Russo, 2001; Shapiro and Rynes, 2005; Tucker, 1994). Only Wholey and Sanchez (1991) explored the normative element of regulatory change in a theoretical piece on the health care industry. Perhaps because they often position the organization as the unit of analysis, management scholars have not analyzed strategic choice under deregulation with an eye toward understanding public goods provision and other 'higher-order' questions.

It is true that economists have focused on the public welfare aspects of deregulation. For example, Winston (1998) summarized the state of knowledge on six deregulated industry sectors, ranging from airlines to banking to natural gas. He concluded that following deregulation all industries displayed strong tendencies to increase consumer welfare via decreased costs and better service. But because Winston focused on the industry as the unit of analysis, individual organizational responses to deregulation were not emphasized. Similarly, studies of public safety elements of deregulation (Alexander, 1992; Rose, 1992) reveal a generally positive relationship between the two but do not address the organizational level of analysis.

As important as these findings are, the link between the strategies of organizations following institutional change and how these strategies impact societal outcomes is poorly understood. Thus, strategists do not have answers to important questions such as these: How do strategic choices made by organizations following deregulation influence the provision of public goods? How does the provision of such public goods reflect the context in which the organization operates? We attempt to address these questions in our analysis. Essentially, we argue that deregulation will create public goods when it acts to permit strategic choices that respond to emergent demand for goods whose consumption has public goods consequences.

Heterogeneity in strategic choice, when combined with the rise of consumer expectations for environmental stewardship, forms the backdrop for our study of deregulation and strategic choice in the electric utility industry. It is instructive to begin with a brief historical sketch of how strategic asymmetries are beginning to appear within the electric utility industry. As we hope to show, this industry and the change that it is now experiencing form an excellent context in which to test theories that we then develop.

\section{Deregulation in the electric power industry}

Until relatively recently, the $\$ 300$ billion U.S. electric power industry consisted mainly of vertically integrated utilities serving various 'service areas' under exclusive franchise agreements. Typically, utilities were vertically integrated, producing power that they then distributed to customers. This arrangement has metamorphosed under deregulation plans that introduced retail competition in California, New York, Illinois, Texas, Michigan, Arizona, New Mexico, and several states in the New England and Mid-Atlantic regions. Prior to retail deregulation, electricity rates were set on a cost recovery basis and customers had one provider to buy from. Investments in physical assets were granted a rate of return, while fuels costs were 
passed through to customers directly. Such an arrangement had its pitfalls, most notably a built-in incentive to overinvest in physical assets (Averch and Johnson, 1962), but did result in a reliable, well-understood mode of operation.

The roots of modern deregulation lie in the Public Utility Regulatory Policies Act (PURPA) of 1978 (Russo, 2001). By forcing utilities to purchase electricity from private generators, policymakers began to see that vertical integration in the industry was not essential to its operation. The law set in motion the processes that have challenged the concept of the utility monopoly and led to significant deregulatory initiatives. The next legislative impetus for restructuring was the Energy Policy Act of 1992. This act set the stage for deregulation by facilitating entry into power sales markets. Critically, it required utilities that owned transmission lines to provide non-discriminatory access to their grids for the purposes of selling wholesale electricity (Brennan, Palmer, and Martinez, 2002). The act thus opened the possibility that states could promote competition not only at the wholesale level but also at the retail level. The Energy Policy Act also delegated to states the power to decide for themselves how to proceed. State regulatory commissions thus were the platform for most of the subsequent initiatives toward electric utility deregulation.

This activity has followed the familiar diffusion process across time, as states adopted retail deregulation at different points in time. California was a leader, as its Public Utilities Commission issued a staff report in 1993 and followed up by formally ruling in favor of retail competition in late 1995. After working its way through the regulatory and legislative process, deregulation began in 1998. As Table 1 shows, deregulation diffused relatively rapidly after that. A frequent sticking point in the negotiations concerning deregulation was the disposition of so-called 'stranded costs.' These were costs for existing plants that were so expensive to build that their power would be uneconomic in a competitive marketplace. In some states, recovery of stranded costs represented a quid pro quo for utilities. Recovery might take place via spreading such stranded costs across all power sold in a state, so that the utility was not competitively disadvantaged. A practice common to all states was the placing of a cap on the prices that utilities could charge under deregulation, and in one state
Table 1. Retail deregulation by state

\begin{tabular}{lc}
\hline State & Year of deregulation \\
\hline Arizona & 1998 \\
Arkansas & 1999 \\
California & 1998 \\
Connecticut & 1998 \\
Delaware & 1999 \\
District of Columbia & 2000 \\
Illinois & 1998 \\
Maine & 1998 \\
Maryland & 1998 \\
Massachusetts & 1998 \\
Michigan & 1998 \\
Montana & 1998 \\
Nevada & 1998 \\
New Hampshire & 1998 \\
New Jersey & 1998 \\
New Mexico & 1999 \\
New York & 1998 \\
Ohio & 1999 \\
Oklahoma & 1998 \\
Oregon & 1999 \\
Pennsylvania & 1998 \\
Rhode Island & 1998 \\
Texas & 1999 \\
Virginia & 1998 \\
Vermont & 1998 \\
West Virginia & 2000 \\
\hline
\end{tabular}

${ }^{a}$ Note: Utilities from other states that did not deregulate by 2000 are also in the sample.

utilities were required to divest their generating assets.

Consistent with other industries, as deregulation has unfolded in the electric generation industry, so has a range of strategic responses. Some firms, such as Montana Power Company, stress low-cost power and focus on minimizing generation costs and prices to consumers. Differentiation also is possible, although it is difficult in this industry because there are few products as quintessentially commoditized as a kilowatt-hour. For this reason, differentiation must take place in other ways, which highlights an important point of connection between deregulation and environmental quality. Differentiating by offering power produced using less environmentally harmful methods is the most prevalent of these strategies.

An example of a utility working to differentiate itself by offering green power is Portland General Electric. The utility works through requests for proposals to add significantly to its 
generation of green electricity. It offers a portfolio of different green power options to customers, designed to connect with whatever might be their environmental leanings. Some of these offerings stress salmon restoration or expanded wind energy use (Portland General Electric Company, 2004).

From the initial sales of green power by several utilities in 1993, the movement has grown to the point where more than 500 investor-owned utilities, municipal utilities, and cooperatives — serving roughly half of America's population-offer green power options for customers (U.S. Department of Energy, 2004). Green power is actively marketed by utilities, employing a myriad of options. In addition to a well-known source, hydroelectricity, they include power from sources as diverse as biomass, wind, solar, geothermal, and landfill gas (U.S. Department of Energy, 2001). According to Bird, Swezey, and Aabakken (2004), the number of customers participating in utility green pricing programs increased fourfold between 1999 and 2002 to a total of 711,500. Although still relatively small in total number, a continuation at anything like this 3-year rate will create sizeable aggregate demand in the next decade. Wiser et al. (2001) projected total demand for green power from 2000 through 2010. Actual experience through 2002 suggests that if the current trends continue demand for green power will quadruple between 2002 and 2010. Though not associated with regulation or deregulation, the supply of green power also is being boosted by programs known as Renewable Portfolio Standards that mandate levels of renewable power used by utilities in a state.

There are several options available to customers to pay for green power, including monthly surcharges, kilowatt-hour premiums, and even voluntary contributions. In 2002 per kilowatt-hour premiums ranged from 0.7 to 17.6 cents/kWh, with a median of 2.5 cents/kWh (Bird et al., 2004). The higher prices charged for green power are attributable to the higher costs faced by providers in securing sources of this power.

The theories that we now develop spotlight how this phenomenon can be viewed as environmental differentiation. We show how attempts of electric companies to lessen their environmental impact and broaden their use of more environmentally sensitive generating technologies represent strategic responses to the early stages of deregulation.

\section{DEREGULATION AND STRATEGIC CHOICE}

Recall that we are interested in how strategic choices made by organizations following deregulation influence the provision of public goods and how this activity reflects the context in which the organization operates. Essentially, we will argue that as deregulation unfolds, choices made by utilities will lead to greater asymmetries among electric providers - and that the extent of environmental differentiation reflects desires within a given organization's service territory for environmental quality. By eliciting differentiation via the provision of power from renewable resources, the end result is improvement of public goods, such as air and water quality.

The critical element of the story is that following deregulation utilities will differentiate in ways that reflect their customers. Under economic regulation, and with monopoly provision of electrical service, there were essentially three types of customers: industrial, commercial, and residential. (It was not quite this simple, since there were differences among the industrial customers in terms of time of use pricing, interruptible service, and so on, but a customer still only had one provider.) For utilities with monopoly franchises, there was little incentive to think further about how customers differed within each of these customer classes.

Other elements of regulation acted to suppress possibilities for green power sales. First, of course, was the fact of monopoly status. Even if there was latent demand for green power among customers, responding to them by unbundling services represented an innovation that utilities would tend to view with skepticism, given the risks of innovation described above (Serchuk and Hirsh, 1998). ${ }^{2}$ Second was the traditional system of utility accounting, which aggregated costs from all types of generation and then apportioned them to kilowatt-hour prices. Under this regime, developed and institutionalized over nearly a century of practice, creating a green power product by pulling out just the costs associated with those plants represented not only a substantial shift in accounting practice but, equally, a profound regulatory challenge

\footnotetext{
${ }^{2}$ While still monopolies, a small number of utilities offered 'green pricing programs,' where customers simply were charged higher prices, with the premium often not linked to any actual source of power (Sweezy, Houston, and Porter, 1998).
} 
(Costello, 1995). These factors worked together to keep potential 'green customers' out of the picture prior to retail deregulation.

However, under deregulation the freedoms conferred on utilities and the competitive threats that they face can be expected to elicit differentiation strategies. These strategies can lead to environmental products succeeding in the marketplace because of the emergence of customer classes that were suppressed under regulation by its historical accounting practices and lack of incentives for innovation. Free to offer green power options, utilities can use such initiatives to differentiate themselves in ways that reflect their new realities under deregulation.

Where might such environmental differentiation strategies emerge first? To address this question, it is instructive to look at differentiation strategies in conceptual terms. The concept of differentiation is simple and well known, and was given its most rigorous treatment in Michael Porter's 1985 treatise, Competitive Advantage (Porter, 1985). Essentially, differentiation is based on the perception of the customer that a product is distinct from those of competitors. There are many points of differentiation, including brand image, quality, features, and service. Differentiation usually inflates the cost of a product or service, so that the firm employing the differentiation strategy will succeed only if the customer sees value in the point of differentiation such that he or she is willing to pay a premium for the product. The differentiator will succeed if this premium is greater than the additional costs incurred by differentiating (e.g., image-related advertising or additional service representatives), and sales volume is sufficient.

As noted, in the electricity industry, one straightforward way to differentiate is by offering green power. Given that there is some evidence of willingness to pay for green power (Byrnes, Jones, and Goodman, 1999) this can be a viable source of differentiation. Evidence suggests that, in fact, green power marketing is enjoying a significant growth spurt in the United States (Bird and Swezey, 2003). On the other hand, at least in the short run, green power has tended to be more expensive than other sources (Burtraw, Palmer, and Heintzelman, 2000), creating the classic differentiation-cost trade-off.

Of great importance is whether or not the point of differentiation is valued by customers, for if they are not willing to pay the premium associated with that differentiation the strategy will fail (Reinhardt,
1998). Almost any type of differentiation will be valued by some customers; the key is to appeal to enough customers to ensure its viability. This is why we believe that the relationship between deregulation and differentiation strategy will be moderated by contextual variables that allow us to capture this valuation. Specifically, we argue that the environmental sensitivity of the population will moderate the relationship, such that the greater that sensitivity the more likely is deregulation to lead to environmental differentiation.

Environmentally sensitive consumers are generally better educated and enjoy higher incomes (Ottman, 1998). And they can be expected to have an effect on the electric utilities performance and behavior-but only where deregulation has been set in motion. Where deregulation is underway and competition can be expected, we believe that environmental differentiation will take place. Customers that value green power will see the chance to purchase it and be more likely to do so.

Thus, institutional change can shift the competitive landscape and offer new opportunities to competitors. A company can make the strategic shifts necessary to meet this interest by shifting its investments to reflect the new strategic imperative. If the firm follows this agenda, it will have to create or purchase the specific assets necessary to respond to the demands of customers. Only by strategically altering its generation mix will it be able to create value by successfully differentiating.

In this sample, where a firm's market reflects environmental sensitivity, we would expect companies to make greater investments to augment their renewable generation. In summary, we hypothesize that environmental differentiation in the electric utility sector will appear under two conditions. First, retail deregulation needs to be in place to allow for differentiation strategies to emerge. Second, demand for environmental quality should be present in the state. We argue that when these two conditions are present firms will have the incentive to pursue environmental differentiation strategies. They will do this by increasing their investments in renewable energy-generating resources. Hence:

Hypothesis 1: Under conditions of deregulation, the greater the level of environmental sensitivity among a generation company's customers, the higher the increase in renewable generation. 
Strategic change must reflect the demands of the marketplace, but it also must respect the realities of the organization undergoing change. An organization's existing competency base can be the result of an initial resource endowment, technological trajectories, luck, and any number of other historical factors (Barney, 1991). When institutional change unveils a new opportunity in a marketplace, firms will assess that opportunity in a heterogeneous fashion. For some, few changes to their resource makeup will be required to pursue it. By leveraging their existing strengths they can exploit the opportunity. For others, developing these resources will threaten long-embedded competencies and competitive advantages, and be less likely to be undertaken.

In the research setting here, investments in renewable energy technologies represent a significant shift from coal-generating technologies for two reasons. Taken together, these will suggest a negative relationship between investments in coal generation and investments in renewables. The first reason has to do with strategy and the development of path-dependent competencies. Coal-fired generation is the beneficiary of generations-long path dependencies that have steadily refined plant designs and operations. Unlike oil-fired plants that have become uneconomic to operate, nuclear power plants which have ceased to be built, or gas-powered plants that serve only peak loads, coal has enjoyed steady popularity as a generating workhorse. For a utility that depends heavily on coal, an expansion to include new technologies such as renewable generation represents a step away from its competency base in large, centralized coal-fired plants.

The second reason for a negative coal-renewables relationship is the issue of reputation, since the greater the level of coal generation, the more difficult will it be for a utility to capture some of the reputational benefits of creating a green electricity presence. Coal-fired electricity generation is known to create a number of health and environmental problems, including respiratory problems and acid rain (Sawin, 2003). To the extent that a firm is heavily invested in coal, it may well suffer from a poor environmental reputation. Without some degree of legitimacy in the eyes of customers, green offerings may be viewed with some suspicion and therefore draw few new customers. One prominent industry working group identified green power as one way to reduce mercury emissions from coal plants-but only if this initiative was accompanied by information on mercury emissions that would educate customers about how their utility's emissions compared to regional averages (U.S. Environmental Protection Agency, 1999). This indicates the difficulty of overcoming the reputational effects of burning coal. Southern Company, one of the nation's most prolific burners of coal, was challenged by the U.S. Public Interest Research group when it tried to polish its green credentials (Odell, 2001). Thus:

\section{Hypothesis 2: Under conditions of deregula- tion, the lower the level of coal generation, the greater the increase in renewable generation.}

The third hypothesis states that the lower the level of productive efficiency of the firm, the greater its investments in renewable technologies. Productive efficiency refers to how, in relation to its peers, a firm can obtain maximum output with given inputs (Farrell, 1957). To the extent that a firm is more efficient, deregulation plays into its strengths and the impetus for differentiation via offering green power is lessened. Put differently, firms that have generating resources that are well matched to the current conditions should be the least likely to initiate or capitalize on new initiatives that require changes to those resources. It is not that there aren't possibilities for efficient firms. Rather, as with utilities heavily invested in coalfired plants, launching initiatives in green power can divert efficient utilities from their strategic intent (Hamel and Prahalad, 1989) and compromise the clarity of their strategy.

By contrast, consider a firm saddled with a relatively inefficient set of generating plants. Here, in the price-competitive world of deregulation, differentiation offers the potential for creating higher margins needed to offset the higher costs due to its inefficiency. And it is important for firms in a deregulated environment to address such inefficiencies, as without monopoly status there can be profound marketplace penalties for inefficiency. Utilities with inefficient plants will see their margins shrink, as they exit the cost-plus regulatory world and enter a world of market-determined power rates that will reflect the entry of low-cost providers. In the inevitable push by such inefficient utilities to find new sources of margins, we expect that they will be more interested in green 
power. As noted above, green power is differentiated and sold to customers who demand it, so it does command a premium in the marketplace. There is evidence of a willingness to pay for green power (Byrnes et al., 1999) and of customer loyalty once in a program (Farhar, 1999). With such prospects for higher margins, there is greater incentive for inefficient utilities to position themselves to sell green power. Hence:

\section{Hypothesis 3: Under conditions of deregulation,} the lower the level of firm productive efficiency, the greater the increase in renewable generation.

It should be borne in mind that nothing prevents a utility's customers from expecting both efficiency and a cleaner environment. And certainly, even the greenest customers expect efficiency at some level. But to the extent that there remain trade-offs between the two, the strategy chosen by the utility (a more efficient utility system that provides private benefits or a more expensive greener utility system with more public benefits) will tend to reflect the underlying population's desires.

\section{METHODOLOGY}

To create our sample, we began with all 177 investor-owned electric utilities, together representing 84 percent of the total U.S. electricity production by privately and publicly owned utilities from 1998 to 2000. These utilities are incumbent firms that were present before and after deregulation. Non-utility generators were excluded due to lack of data. Because we employed a lagged variable approach for these tests to account for prior causality and a change between two consecutive years as a dependent variable, we lost one year from the analysis. There were missing data for one or more variables, leaving 114 utilities with complete data records for the two years. Our final sample thus contained 228 observations. Utilities in the sample represent $61 \%$ of U.S. electricity production.

We utilized a combination of several databases, mainly the Federal Energy Regulatory Commission Form Number 1 (FERC Form 1; U.S. Department of Energy, 1998-2000) and the Emissions and Generation Resource Integrated Database (EGRID; U.S. Environmental Protection Agency,
2002). The FERC Form 1, the Annual Report for Major Electric Utilities, is filed by major electric utilities. ${ }^{3}$ The report for each utility, averaging a hefty 140 pages, contains general corporate information, financial statements and supporting schedules, and a wealth of engineering statistics. EGRID contains emissions and resource mix data for essentially all U.S. electricity generating plants. EGRID contains information from three federal agencies: the U.S. Environmental Protection Agency (EPA), the U.S. Energy Information Administration (EIA), and the Federal Energy Regulatory Commission (FERC). EGRID aggregates the data from the plant level to the utility company level, providing a detailed emissions profile, as well as the generation resource mix and capacity, ownership, corporate affiliation and location information, and other pertinent variables.

To test our hypotheses, we estimated changes in the generation mix that reflect strategic choices made by utilities.

\section{Dependent variable}

\section{Change in percentage of generation from renewables}

This variable represents the yearly changes in percentages of renewable generation as a percentage of the electricity generated by a utility. Using information from the EGRID database, we calculated the difference between the percentages of renewable generation in two consecutive years:

$$
\begin{aligned}
\underset{\text { Dependent }}{\text { variable }} & =\left(\begin{array}{l}
\text { Generation from }^{\text {renewables }_{t}} \\
\text { Total }_{\text {generation }}
\end{array} * 100\right) \\
& -\left(\begin{array}{l}
\text { Generation from }^{\text {renewables }_{t-1}} \\
\text { Total }_{\text {generation }_{t-1}}
\end{array}\right) 100
\end{aligned}
$$

\footnotetext{
${ }^{3}$ Major electric utilities are classified as those with annual sales or transmission service that exceeds one of the following: (1) 1,000,000 megawatt hours of total annual sales; (2) 100 megawatt hours of annual sales for resale; (3) 500 megawatt hours of gross interchange out; or (4) 500 megawatt hours of wheeling for others (deliveries plus losses).
} 


\section{Independent variables}

\section{Deregulation}

To pick up the effect of deregulation, we created a time-changing variable that represents whether or not retail deregulation policy had been enacted in a given state. To do so, we used information from the U.S. Department of Energy (2000). Although the particulars of the policies varied across jurisdictions, the formal adoption of retail deregulation is an important threshold that is tractable and consistent across states. ${ }^{4}$ The creation of this variable for a given utility is complicated, however, because 17 percent of our utilities operate in both regulated and deregulated states. To address this issue, we followed Delmas and Tokat (2005) and created a time-changing variable that takes the value of 1 starting in the year in which retail deregulation was enacted or a regulatory order was issued, and 0 otherwise. This variable was then weighted based on the percentage of electricity sold by the utility in each state to create the variable deregulation used in the regression.

There are other types of deregulation that states adopted, sometimes in concert with retail deregulation. Two such policies were (a) to require utilities to divest their generating assets and (b) to allow the recovery of stranded costs (costs associated with plants approved and built in the monopoly era that were too expensive to be viable in a competitive context). To explore the sensitivity of our results to other types of deregulation, we created two additional variables that represent whether (a) there was retail deregulation and the recovery of stranded costs was allowed, and (b) there was retail deregulation but recovery of stranded costs was disallowed (see Delmas and Tokat, 2005). ${ }^{5}$ The results of the regressions with these variables are not significantly different from the ones that are presented in this paper and are available upon request from the authors.

\footnotetext{
${ }^{4}$ Recall that retail deregulation did not confer complete freedom on competitors, as in every case the state placed a cap on prices when it adopted retail deregulation.

${ }^{5}$ Only one utility in our sample belongs to a state that required firms to divest their assets, so we could not use 'deregulation with divesture' as a separate category. The observations of this utility were classified in the deregulation 'only' group. The results are the same without this utility.
}

\section{Environmental sensitivity}

The environmental sensitivity of the citizens of the state in which the firm operates plays a pivotal role in our story. Several prior researchers have used the scores of the League of Conservation Voters (LCV) as a measure of the environmental sentiment of the people of a state (Gray, 1997; Terry and Yandle, 1997). ${ }^{6}$ Each year, the LCV selects environmental issues that constitute the environmental agenda with a panel comprising the main U.S. environmental groups. The organization then creates an index by counting the number of times that each representative or senator in Congress votes in favor of the 'environmental agenda' (e.g., against logging in national forests or for proper mining waste disposal). The index ranges from 0 to 100 , with 100 representing a record of voting with the environmental agenda in all cases. Following Kahn (2002) and Levinson (1999), the raw variable is calculated as the average of the environmental scores of members of the U.S. House of Representatives and Senate. We then weighted this average by the total number of Congressional representatives in each state and by the percentage of generation of each firm in each state. Our source for voting scores was the League of Conservation Voters $(1998,1999)$.

\section{Percentage of generation from coal}

To create this variable, we used EGRID to calculate the percentage of electricity generated by coal.

\footnotetext{
${ }^{6}$ To verify that LCV ratings do reflect the environmental sentiment of the state's population generally, we attempted to validate them by comparing them to percentage of the state's residents that are members of the Sierra Club. We had membership data only for 2004, so it could not be used in the analysis. But the correlation between the $2004 \mathrm{LCV}$ average rating for a state and the percentage of its residents that were Sierra Club members in 2004 was 0.45 . This suggests that the LCV ratings are a reasonable measure of the strength of state-wide environmental sensitivity. In theory, it could be the case that the character of a state's politics, picked up by the Environmental Sensitivity variable, might also suggest pro-deregulation sentiment. This endogeneity problem, however, is not shown in an analysis of the determinants of deregulation by the states. Ando and Palmer (1998) explored early moves toward deregulation by state commissions and legislatures, and found that in six regression equations the LCV rating only predicted state action in one, with a negative effect. This indicates that endogeneity is not an issue in our model.
} 


\section{Efficiency}

We estimated productive efficiency using Data Envelopment Analysis (DEA) (Charnes, Cooper, and Rhodes, 1978; Banker, Charnes, and Cooper, 1984). The DEA technique uses linear programming to convert multiple input and output measures into a single measure of relative efficiency for each observation. Further details on DEA and how we used it appear in the Appendix.

\section{Control variables}

\section{Renewables}

We needed to control for the presence of the firm's previous investments in renewables and to avoid multicollinearity problems with the coal generation variable. In doing so, we also needed to avoid overdetermination with the dependent variable. So we included a dummy variable to represent whether a utility has made some investment in renewables at $t-1$. The variable takes the value of 1 when a utility is generating electricity from renewables at $t-1$, and 0 when the utility is not generating electricity from renewables at $t-1 .^{7}$

\section{New entrants}

The number of new entrants in the competitive environment where the utility operates may impact the incumbent firms' strategies. We created a variable that represents the number of new firms entering the state's market divided by the total number of firms per state and year. This measure was then weighted based on the percentage of electricity sold in each state for multi-states utilities. We constructed this variable using the entire U.S. electric utility population (i.e., investorowned, public-owned, cooperative and federal utilities). The information came from the U.S. Energy Information Administration, Form EIA-861 (1998, 1999).

\footnotetext{
${ }^{7}$ To further consider the possibility that utilities may have 'prepositioned' themselves for coming deregulation, we collected data on two types of renewables (hydroelectric facilities and non-hydroelectric facilities) for utilities in each of the years 1997-2000. We found no significant differences for either category in 1997. From 1998 through 2000, states that implemented deregulation did not see a significant difference for hydroelectric facilities. However, for those same three years, states that deregulated witnessed a significant increase in renewables when compared to non-deregulating states.
}

\section{Renewables portfolio standard in place}

This variable captures the effect of operating in a state with an established renewable portfolio standard (RPS). An RPS mandates that utilities generate a specified proportion of their energy from renewable sources. We first created a variable that takes the value 1 in the year a state has enacted RPS and the following years, and 0 otherwise. The data for this variable were derived from the National Database of State Incentives for Renewable Energy (Interstate Renewable Energy Council, 2004). For multi-state utilities, this variable was weighted based on the percentage of electricity sold within each state by the utility.

\section{TRI/area}

To pick up the influence of environmental conditions in the state, we included a variable to proxy the level of emissions in the states where the utility operates in analyses. Following King and Lenox (2000) and Kassinis and Vafeas (2002), we used the state's toxic emissions (the total amount of on-site and off-site toxic release) from the U.S. Environmental Protection Agency (EPA) Toxics Release Inventory (TRI) database (U.S. Environmental Protection Agency, 1998-1999), and then divided this number by the state's land area (U.S. Census Bureau, 2000). For firms that operate in several states, we weighted this measure by the percent of electricity generated in each state. If more polluted states gain more from clean production, this variable will pick up the effect.

\section{Residential proportion of customers}

This variable was included to pick up the effect of differences in the types of customers served by the utility. If residential customers are more receptive to renewable generation, then the coefficient on this variable should be positive. The variable is the ratio of residential sales divided by the total sales to ultimate consumers in megawatt hours. The data came from FERC Form 1 reports.

\section{Annual net generation}

To proxy the size of the firm we used the annual net generation of the firm in megawatt hours given in the EGRID database. A logarithmic transformation was used to reduce skewness. 


\section{Average plant age}

The age of the generators could influence the ability of a utility to create change. The older the average plant age, the easier it might be to justify investments in new technologies like renewables. Alternatively, old plants could reflect an organizational inertia that might inhibit investments in new technologies. Using EGRID, we computed the average number of years since the installation of each generating unit. The aggregation at the utility level was based on the percentage of ownership of each generating unit.

\section{Research and development}

This variable represents the research and development expenses divided by the total operational expenses that the utility reports to FERC. Firms with greater investments in $R \& D$ may have a higher probability of investing in renewables than those that invest less in R\&D. A logarithmic transformation of this variable was used to reduce skewness.

\section{Merger process with gas or electricity utilities}

We also controlled for the effects of merger activity. From 1995 to 2000, 36 mergers or acquisitions were completed between investor-owned electric utilities or between investor-owned electric utilities and independent power producers (U.S. Department of Energy, 2000). ${ }^{8}$ We measured whether an electric utility went through a merger with other electric utilities or non-utility power producers, or with gas producers. A merger with an electricity company was considered as a related merger, and a merger with a gas company corresponded to a diversification strategy. When a firm goes through a merger, there is uncertainty about whether the merger will be accepted and how to merge the assets of the different companies. In addition, during the merger process, there can be changes in the structure of the firm. For example, firms may decide to downsize their labor force or adopt similar technologies in the merged facilities or retire some of their facilities. During this adjustment period, it is possible that a firm will slow down other strategic moves such as the

\footnotetext{
${ }^{8}$ We obtained additional information on the mergers from the FERC website: http://www.ferc.gov/industries/electric/geninfo/mergers/merger-apps.asp.
}

adoption of an environmental differentiation strategy. If the utility itself or its holding company goes through a merger process, then the indicator was 1 the year before until the year after the merger is completed (i.e., if the merger took place in year 1999, the indicator would be 1 for the years 1998 and 1999).

\section{Interconnected network membership}

We controlled for location in a specific interconnected network to which the electric utility belongs. An interconnected network (or power grid) consists of extra-high-voltage connections between utilities designed to distribute the electrical energy from one part of the network to another. Transfers between networks are nearly impossible because there are few lines that connect them. Following the U.S. Energy Information Administration, we used the following three major networks: (1) the Eastern Interconnected System, consisting of the eastern two-thirds of the United States; (2) the Western Interconnected System, consisting primarily of the Southwest and areas west of the Rocky Mountains; and (3) the Texas Interconnected System, consisting mainly of Texas. Each firm in our sample belongs to one of three of these networks, so we omitted the Eastern network to avoid overdetermination.

\section{Year effects}

We included a dummy variable for the year 1999 to pick up any effects specific to the years in the analysis.

\section{Estimation method}

We performed a pooled OLS estimation regression. We used the Cook-Weisberg and the White test statistics to check the homoscedasticity assumption and found the presence of heteroscedasticity (Cook and Weisberg, 1983; White 1980). In order to correct for heteroscedasticity, we used a robust-cluster estimator of the standard errors in our regressions. The robust-cluster variance estimator is a variant of the Huber-White robust estimator, which provides correct standard errors in the presence of any pattern of heteroscedasticity. It also remains valid and provides correct coverage in the presence of any pattern of correlation among errors within units. This estimator allowed us to relax 
the assumption of independence of errors in the regressions. Since we used a pooled time-series approach, repeated observations may create correlated error terms and inflate $t$-statistics without using this correction. ${ }^{9}$ The robust-cluster estimator produces correct standard errors even when the observations are correlated within clusters (StataCorp, 1999).

Another alternative approach is to use a panel data regression with firm random effects, where the error term contains a unit specific component as randomly distributed across cross-section units. This method takes into account the individuallevel differences between utilities over time, capturing this heterogeneity in the error term. We estimated the model using the option of Huber-White estimator of standard errors to correct for heteroscedasticity. The results using this specification match the results using pooled OLS with robustcluster estimator of the standard errors. ${ }^{10}$ However, the Lagrange multiplier test (Breusch and Pagan,

\footnotetext{
${ }^{9}$ The robust-cluster standard errors are unaffected by the presence of unmeasured firm-specific factors causing correlation among errors of observations for the same firm, or for that matter any other form of within-unit error correlation.

${ }^{10}$ Random effects estimates (available from the authors) show very similar effect sizes and an identical pattern of significance for controls and independent variables.
}

1980) for the random-effects model suggests that the pooled regression model is the most suitable.

To test our hypotheses, we needed to interact the variables measuring deregulation and environmental sensitivity in a state (Hypothesis 1), deregulation and percentage of generation from coal (Hypothesis 2), and deregulation and efficiency (Hypothesis 3). To avoid multicollinearity, we first de-meaned these variables, and then computed the interaction terms as the product of each pair of de-meaned variables. All right-hand-side variables were lagged 1 year.

\section{RESULTS}

Tables 2 and 3 display descriptive statistics and correlations for the variables used in the analysis. The collinearity diagnostics, including variance inflation factors, indicate that multicollinearity was not a problem in the statistical analysis. The pooled OLS regression results with robust-cluster robust estimator are presented in Table 4.

In Table 4, Model A presents the results of the regression with the control variables, and serves as a baseline model. In Model B, we include the variables that represent whether or not deregulation has been enacted and the environmental sensitivity of the population. In Model $\mathrm{C}$, we test Hypothesis 1

Table 2. Descriptive statistics

\begin{tabular}{|c|c|c|c|c|c|}
\hline Variable & $\mathrm{N}$ & Mean & S.D. & Min & Max \\
\hline Change in percentage of generation by renewables & 228 & 1.39 & 10.72 & -16.45 & 64.40 \\
\hline Deregulation & 228 & 0.42 & 0.48 & 0.00 & 1.00 \\
\hline League of Conservation Voters (LCV) rating & 228 & 43.55 & 22.30 & 2.00 & 96.67 \\
\hline Percentage of generation from coal & 228 & 53.51 & 39.46 & 0.00 & 99.97 \\
\hline Efficiency & 228 & 92.59 & 9.45 & 52.90 & 100.00 \\
\hline Deregulation $\times \mathrm{LCV}$ rating & 228 & 4.33 & 10.13 & -22.37 & 27.66 \\
\hline Deregulation $\times$ Coal & 228 & 4.11 & 18.49 & -27.20 & 27.06 \\
\hline Deregulation $\times$ Efficiency & 228 & 0.50 & 4.40 & -10.97 & 18.11 \\
\hline Renewables (dummy) & 228 & 0.49 & 0.50 & 0.00 & 1.00 \\
\hline New entrants & 228 & 0.02 & 0.07 & 0.00 & 0.37 \\
\hline Renewables portfolio standard & 228 & 0.12 & 0.31 & 0.00 & 1.00 \\
\hline TRI/Area & 228 & 1.32 & 1.12 & 0.01 & 4.02 \\
\hline Residential proportion of customers & 228 & 0.29 & 0.13 & 0.00 & 0.53 \\
\hline Annual net generation (log scale) & 228 & 15.31 & 2.38 & 6.56 & 18.23 \\
\hline Average plant age & 228 & 29.63 & 10.65 & 3.49 & 78.00 \\
\hline Research and development (log scale) & 228 & 0.81 & 0.78 & 0.00 & 3.61 \\
\hline Merger process with gas utility & 228 & 0.06 & 0.24 & 0.00 & 1.00 \\
\hline Merger process with electric utility & 228 & 0.25 & 0.43 & 0.00 & 1.00 \\
\hline Eastern interconnected system & 228 & 0.80 & 0.40 & 0.00 & 1.00 \\
\hline Western interconnected system & 228 & 0.14 & 0.34 & 0.00 & 1.00 \\
\hline Texas interconnected system & 228 & 0.03 & 0.17 & 0.00 & 1.00 \\
\hline
\end{tabular}




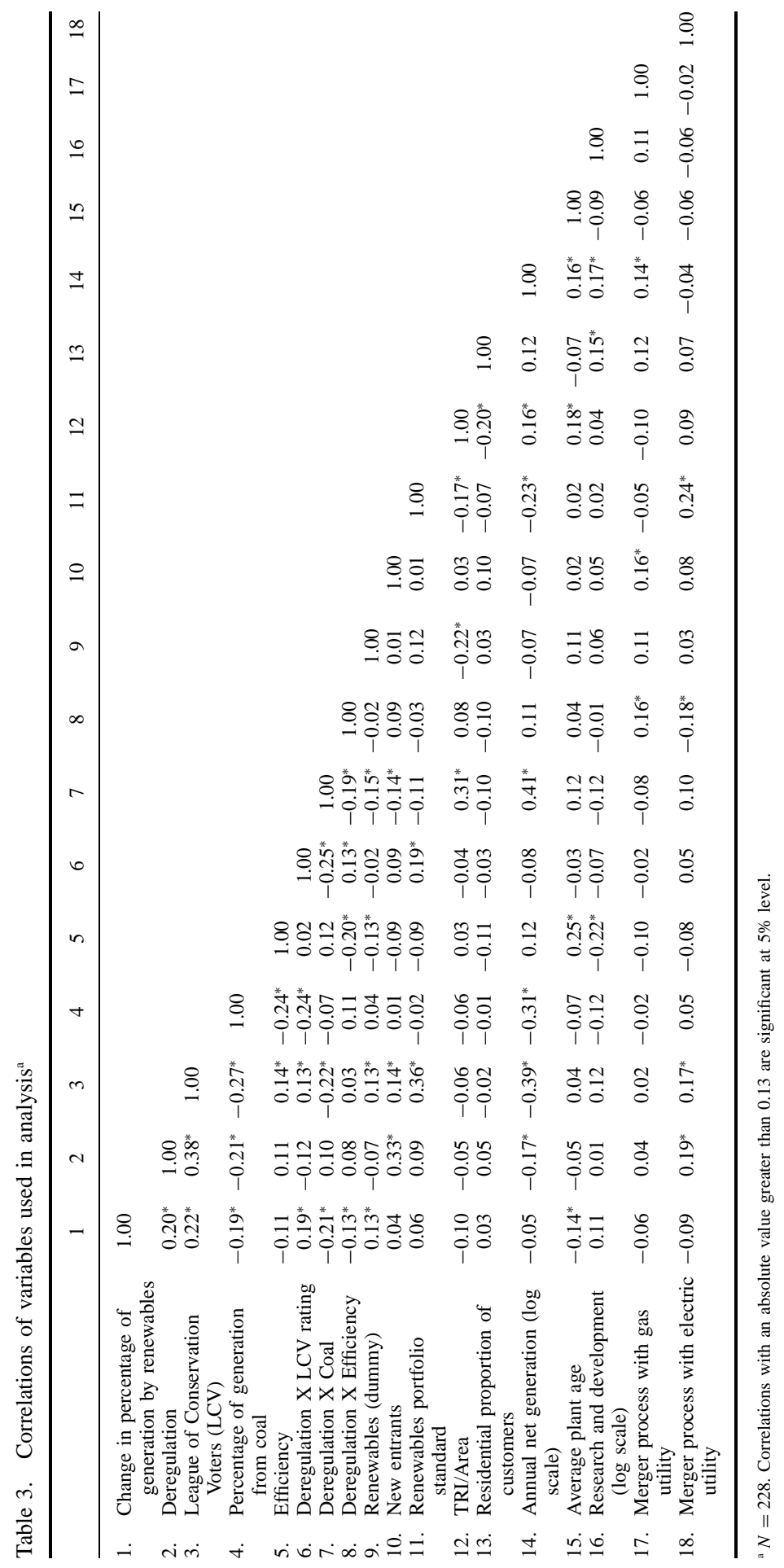


Table 4. Pooled regression results

Dependent variable: change in percentage of generation by renewables ${ }^{\mathrm{a}}$

\begin{tabular}{|c|c|c|c|c|c|c|}
\hline & (A) & (B) & (C) & (D) & (E) & (F) \\
\hline Deregulation & & $\begin{array}{l}4.951 \\
(1.614)^{* *}\end{array}$ & $\begin{array}{l}5.277 \\
(1.592)^{* *}\end{array}$ & $\begin{array}{l}5.253 \\
(1.605)^{* *}\end{array}$ & $\begin{array}{l}5.433 \\
(1.597)^{* *}\end{array}$ & $\begin{array}{c}6.184 \\
(1.559)^{* *}\end{array}$ \\
\hline League of Conservation Voters (LCV) rating & & $\begin{array}{c}0.092 \\
(0.040)^{*}\end{array}$ & $\begin{array}{c}0.088 \\
(0.039)^{*}\end{array}$ & $\begin{array}{c}0.076 \\
(0.040)^{+}\end{array}$ & $\begin{array}{c}0.085 \\
(0.039)^{*}\end{array}$ & $\begin{array}{c}0.064 \\
(0.038)^{+}\end{array}$ \\
\hline Percentage of generation from coal & $\begin{array}{l}-0.085 \\
(0.023)^{* *}\end{array}$ & $\begin{array}{c}-0.075 \\
(0.022)^{* *}\end{array}$ & $\begin{array}{c}-0.068 \\
(0.022)^{* *}\end{array}$ & $\begin{array}{c}-0.081 \\
(0.022)^{* *}\end{array}$ & $\begin{array}{c}-0.068 \\
(0.022)^{* *}\end{array}$ & $\begin{array}{l}-0.063 \\
(0.022)^{* *}\end{array}$ \\
\hline Efficiency & $\begin{array}{c}-0.198 \\
(0.079)^{*}\end{array}$ & $\begin{array}{c}-0.261 \\
(0.077)^{* *}\end{array}$ & $\begin{array}{c}-0.264 \\
(0.076)^{* *}\end{array}$ & $\begin{array}{l}-0.245 \\
(0.077)^{* *}\end{array}$ & $\begin{array}{l}-0.299 \\
(0.077)^{* *}\end{array}$ & $\begin{array}{c}-0.297 \\
(0.075)^{* *}\end{array}$ \\
\hline Efficiency $\times$ LCV rating & & & $\begin{array}{c}0.190 \\
(0.068)^{* *}\end{array}$ & & & $\begin{array}{c}0.192 \\
(0.069)^{* *}\end{array}$ \\
\hline Deregulation $\times$ Coal & & & & $\begin{array}{c}-0.085 \\
(0.039)^{*}\end{array}$ & & $\begin{array}{c}-0.078 \\
(0.039)^{*}\end{array}$ \\
\hline Deregulation $\times$ Efficiency & & & & & $\begin{array}{c}-0.432 \\
(0.154)^{* *}\end{array}$ & $\begin{array}{c}-0.560 \\
(0.152)^{* *}\end{array}$ \\
\hline Renewables (dummy) & $\begin{array}{c}2.718 \\
(1.449)^{+}\end{array}$ & $\begin{array}{c}3.036 \\
(1.399)^{*}\end{array}$ & $\begin{array}{c}2.961 \\
(1.377)^{*}\end{array}$ & $\begin{array}{c}2.620 \\
(1.400)^{+}\end{array}$ & $\begin{array}{c}2.981 \\
(1.377)^{*}\end{array}$ & $\begin{array}{c}2.506 \\
(1.347)^{+}\end{array}$ \\
\hline New entrants & $\begin{array}{c}0.341 \\
(1.130)\end{array}$ & $\begin{array}{c}-1.007 \\
(1.118)\end{array}$ & $\begin{array}{c}-1.073 \\
(1.100)\end{array}$ & $\begin{array}{r}-1.286 \\
(1.115)\end{array}$ & $\begin{array}{r}-0.727 \\
(1.104)\end{array}$ & $\begin{array}{c}-0.965 \\
(1.075)\end{array}$ \\
\hline Renewables portfolio standard & $\begin{array}{c}0.667 \\
(2.436)\end{array}$ & $\begin{array}{c}-0.584 \\
(2.485)\end{array}$ & $\begin{array}{c}0.262 \\
(2.463)\end{array}$ & $\begin{array}{c}-0.477 \\
(2.463)\end{array}$ & $\begin{array}{c}0.792 \\
(2.494)\end{array}$ & $\begin{array}{c}2.153 \\
(2.444)\end{array}$ \\
\hline TRI emissions/Area & $\begin{array}{r}-0.241 \\
(0.794)\end{array}$ & $\begin{array}{r}-0.131 \\
(0.758)\end{array}$ & $\begin{array}{r}-0.029 \\
(0.746)\end{array}$ & $\begin{array}{r}-0.117 \\
(0.751)\end{array}$ & $\begin{array}{r}-0.203 \\
(0.746)\end{array}$ & $\begin{array}{r}-0.109 \\
(0.723)\end{array}$ \\
\hline Residential proportion of customers & $\begin{array}{r}-2.811 \\
(5.757)\end{array}$ & $\begin{array}{r}-2.570 \\
(5.492)\end{array}$ & $\begin{array}{r}-2.184 \\
(5.405)\end{array}$ & $\begin{array}{r}-3.380 \\
(5.456)\end{array}$ & $\begin{array}{r}-2.998 \\
(5.406)\end{array}$ & $\begin{array}{c}-3.483 \\
(5.256)\end{array}$ \\
\hline Annual net generation (log scale) & $\begin{array}{c}0.749 \\
(0.378)^{*}\end{array}$ & $\begin{array}{c}1.117 \\
(0.377)^{* *}\end{array}$ & $\begin{array}{c}1.297 \\
(0.377)^{* *}\end{array}$ & $\begin{array}{c}1.168 \\
(0.375)^{* *}\end{array}$ & $\begin{array}{c}1.046 \\
(0.372)^{* *}\end{array}$ & $\begin{array}{c}1.253 \\
(0.365)^{* * *}\end{array}$ \\
\hline Average plant age & $\begin{array}{c}-0.198 \\
(0.069)^{* *}\end{array}$ & $\begin{array}{l}-0.178 \\
(0.066)^{* *}\end{array}$ & $\begin{array}{c}-0.157 \\
(0.065)^{*}\end{array}$ & $\begin{array}{c}-0.139 \\
(0.068)^{*}\end{array}$ & $\begin{array}{l}-0.185 \\
(0.065)^{* *}\end{array}$ & $\begin{array}{c}-0.128 \\
(0.065)^{+}\end{array}$ \\
\hline Research and development (log scale) & $\begin{array}{c}0.216 \\
(0.953)\end{array}$ & $\begin{array}{r}-0.198 \\
(0.922)\end{array}$ & $\begin{array}{c}0.091 \\
(0.913)\end{array}$ & $\begin{array}{c}-0.479 \\
(0.923)\end{array}$ & $\begin{array}{c}-0.306 \\
(0.909)\end{array}$ & $\begin{array}{r}-0.304 \\
(0.900)\end{array}$ \\
\hline Merger process with gas & $\begin{array}{c}-1.771 \\
(3.101)\end{array}$ & $\begin{array}{r}-2.103 \\
(2.969)\end{array}$ & $\begin{array}{r}-2.477 \\
(2.924)\end{array}$ & $\begin{array}{c}-2.796 \\
(2.960)\end{array}$ & $\begin{array}{r}-1.646 \\
(2.926)\end{array}$ & $\begin{array}{c}-2.524 \\
(2.848)\end{array}$ \\
\hline Merger process with electric utility & $\begin{array}{c}-2.613 \\
(1.702)\end{array}$ & $\begin{array}{l}-4.396 \\
(1.665)^{* *}\end{array}$ & $\begin{array}{l}-4.956 \\
(1.650)^{* *}\end{array}$ & $\begin{array}{l}-4.410 \\
(1.650)^{* *}\end{array}$ & $\begin{array}{l}-4.874 \\
(1.647)^{* *}\end{array}$ & $\begin{array}{c}-5.594 \\
(1.611)^{* *}\end{array}$ \\
\hline Western interconnected system & $\begin{array}{c}-5.185 \\
(2.548)^{*}\end{array}$ & $\begin{array}{l}-4.810 \\
(2.463)^{+}\end{array}$ & $\begin{array}{c}-3.911 \\
(2.445)\end{array}$ & $\begin{array}{c}-4.307 \\
(2.452)^{+}\end{array}$ & $\begin{array}{l}-5.176 \\
(2.427)^{*}\end{array}$ & $\begin{array}{c}-3.915 \\
(2.373)\end{array}$ \\
\hline Texas interconnected system & $\begin{array}{r}-4.262 \\
(4.213)\end{array}$ & $\begin{array}{r}-1.972 \\
(4.084)\end{array}$ & $\begin{array}{r}-1.434 \\
(4.022)\end{array}$ & $\begin{array}{c}-1.869 \\
(4.048)\end{array}$ & $\begin{array}{r}-2.797 \\
(4.029)\end{array}$ & $\begin{array}{c}-2.407 \\
(3.905)\end{array}$ \\
\hline Year 1999 & $\begin{array}{c}2.393 \\
(1.450)\end{array}$ & $\begin{array}{c}2.004 \\
(1.414)\end{array}$ & $\begin{array}{c}1.814 \\
(1.393)\end{array}$ & $\begin{array}{c}1.816 \\
(1.404)\end{array}$ & $\begin{array}{c}1.920 \\
(1.392)\end{array}$ & $\begin{array}{c}1.529 \\
(1.352)\end{array}$ \\
\hline Constant & $\begin{array}{l}18.361 \\
(9.118)^{*}\end{array}$ & $\begin{array}{l}19.019 \\
(8.699)^{*}\end{array}$ & $\begin{array}{l}14.199 \\
(8.728)\end{array}$ & $\begin{array}{l}16.286 \\
(8.712)^{+}\end{array}$ & $\begin{array}{l}17.900 \\
(8.735)^{*}\end{array}$ & $\begin{array}{l}17.985 \\
(8.593)^{*}\end{array}$ \\
\hline Observations & 228 & 228 & 228 & 228 & 228 & 228 \\
\hline Adj. $R^{2}$ & 0.12 & 0.20 & 0.22 & 0.21 & 0.22 & 0.27 \\
\hline Incremental $F$-test (Reference Model: A) & & $11.51^{* *}$ & $10.58^{* *}$ & $9.47^{* *}$ & $10.56^{* *}$ & $9.91^{* *}$ \\
\hline
\end{tabular}

${ }^{a}$ Robust standard errors in parentheses.

+ Significant at $10 \% ;{ }^{*}$ significant at $5 \%$; ${ }^{* *}$ significant at $1 \%$

by incorporating the interaction effect between deregulation and the environmental sensitivity of the population in the state. In Model D, we test Hypothesis 2 by adding the interaction effect between deregulation and the percentage of generation from coal. In Model E, we test Hypothesis
3 by adding the interaction effect between deregulation and efficiency. Model F is the full model. As the adjusted $R^{2}$ statistics and incremental $F$ tests show, compared to Model A each addition of new variable(s) significantly improves the fit of the model. 
We find that the coefficient of the variable representing the percentage of coal used in the production mix is negative and significant at the 1 percent level in all models. In our sample, the higher the percentage of coal generation, the lower the increase in the generation from renewables the following year. The coefficient of the variable representing firm's efficiency is negative and significant at the 5 percent level in Model A, and at the 1 percent level in Models B to F. This indicates that firms enjoying higher levels of efficiency are less likely to increase their generation from renewables. The coefficients for the variable capturing whether the firm had already made some investments in renewables are positive and significant, showing that these firms are more likely to increase their generation from renewables in the next year.

Several other variables are significant. The variable representing the size of utilities is positively and significantly associated with the dependent variable throughout the models. The variable representing the average plant age is negative and significant in all the models. Thus, expansion of renewable generation is more rapid for larger and younger companies. Finally, the coefficients of the variable representing merger activities with electric utility companies is negative and significant in Models B-F, showing that companies that are engaged in merger processes invest less in renewables. This may have to do with the difficulty of taking a new strategic path while integrating two companies. The effect of being inter-tied to the Western power grid is weakly significant in several equations as well.

The coefficients on variables representing deregulation and the environmental sensitivity of the population in the state are positive and significant at $1-10$ percent level respectively in Models B through F. The finding of a positive direct effect for deregulation on investments in renewables is itself a noteworthy result. This may indicate that since all states presumably have some green consumers, a basic level of activity appeared throughout the country following deregulation.

In Model C, the interaction term between deregulation and the environmental sensitivity of the population in the state is positive and significant at the 1 percent level. In deregulated states, firms located where citizens display greater environmental sensitivity increase the share of renewables in their production mix more than firms that operate only in deregulated states or only in states with a high environmental sensitivity. Thus, Hypothesis 1 is supported. In Model D, the interaction term between deregulation and the percentage of generation from coal is negative and significant at the 5 percent level. In deregulated states, the more firms rely on coal, the less they will increase their generation from renewables in the following year. This finding is consistent with Hypothesis 2. The interaction term between deregulation and firms' efficiency is negative and significant at the 1 percent level in Model E. So in deregulated states, increases in efficiency dampen the positive effect of deregulation on increased generation from renewables. This result supports Hypothesis 3. In Model F, all interaction terms retain their signs and level of significance, confirming all of the hypotheses.

\section{Limitations}

We must note some limitations to our analysis. Confidence in our results would be enhanced if we had more years of data in our analysis. Also, we did not control for firm-specific unobserved heterogeneity. For this reason, if there are omitted variables that systematically covary with independent variables, it is possible that our analysis is picking up their effects rather than the variables that we used. Finally, we did not have information on the exact nature of price premiums being charged for green power. This information could have been used to more clearly specify the cause-effect chain.

\section{DISCUSSION AND CONCLUSION}

\section{Institutional change and strategic choice}

We find that utilities were more likely to take strategic actions to support an environmental differentiation strategy following deregulation in states where citizens display higher degrees of environmental sensitivity. Under deregulation, however, incumbent firms that relied heavily on coal-fired generation or enjoyed strong productive efficiencies were less likely to adopt such strategies. These results allow us to conclude that deregulation has led to a series of strategic choices by which utilities connected their power offerings both to the context in which they operated and to their particular endowment of organizational resources. 
Taken alone, this outcome resembles a competitive context. But institutional change like deregulation influences strategic choices in a unique way. Seen in retrospect, regulation acted as a shaper and delimiter of resource development and the set of opportunities open to a firm, and in essence mandated path dependencies. This typically is manifested in statutory limits on domains of activity, such as when savings and loans could not develop competencies outside of residential lending or when AT\&T was barred from developing resources to serve telecommunications markets overseas from 1934 until 1984. What we discovered in our analysis was that the external environment faced by utilities also is strongly shaped by regulation in ways that push them on particular strategic paths. It was not that utilities were prevented from developing green power resources (and of course, several of them did so). Rather, it was their monopoly status and the nature of utility regulation that blocked incentives for offering green power as a new retail product, in turn biasing downward opportunities for utilities to promote renewable generation.

Our study thus suggests two points to consider about the post-deregulation marketplace. The first is that the marketplace under regulation was not allowed to develop and mature in ways that would have demonstrated the viability of new customer classes. Latent demand for differentiated services was suppressed. In short, the richness of product offerings that characterizes so many markets for consumer goods was absent under regulation. While many observers, especially economists, have applauded how deregulation has boosted consumer welfare via lower prices, few have highlighted the many product innovations that deregulation also elicited once firms were able to energize latent markets (e.g., Winston, 1998).

The second and related point is that shifts in the institutional environment often generate significant marketplace discontinuities (Haveman et al., 2001). As just noted, one of the reasons that such discontinuities are so striking is simply that customer segments were suppressed under regulation. It is easy to see how deregulation can create unpredictable change, a competitive landscape of heterogeneous strategies, and winners and losers when a new freedom to take strategic action coincides with the sudden unleashing of marketplace demands. In our case, environmental differentiation ensued.

\section{Environmental differentiation in action}

Our results indicate that the environmental sensitivity of the populace served by a utility was reflected in its managerial actions. In other industries, the idea that companies would act in accordance with the preferences of their customers is hardly a subject for lively debate. But it is news in this industry, as market-like behavior supplanted the more paternalistic approach under regulation. Historically, regulatory commissions were expected to articulate the desires and protect the interests of the populace, in theory creating efficient and socially optimum outcomes. However, even when commissions acted in the public interest (as opposed to being dominated by the companies they regulated), their mission was conceived narrowly. Although occasionally playing different roles in promoting alternative technologies (Russo, 2001), mandating a particular structure for pricing (Shepherd, 1985) and so on, most commissions focused their energy on scrutinizing the cost structure of utilities. Their collective attention was directed to review of rates charged to customers and two associated areas: fuel and construction costs.

Slowly, deregulation is metamorphosing this industry. In the world of utilities, as deregulation unfolds, the power to influence their activities and policies is migrating from regulatory commissions expected to represent customers to the customers themselves. And that change has potentially profound ramifications. Under traditional utility regulation, a clearly defined institutional apparatus developed to bond utilities and commissions. Across nearly a century of use, this apparatus became standardized and the regulatory agenda became defined and constrained (Gormley, 1983). As with the prototypical institutional process, the idea of vertically integrated monopoly achieved taken-for-granted status. This was only challenged with the passage of PURPA, which unexpectedly created the conditions for competition in this world (Joskow, 1997).

For the foreseeable future, the electric generation industry will retain a strong institutional character. However, our results indicate the beginnings of behavior consistent with more market-like tendencies. Environmental differentiation by firms, especially when the populace they serve is most likely to value that differentiation, was very much 
in evidence in our sample. Essentially, this differentiation acts in ways that Porter (1985) and others would expect: it creates value by identifying an underserved constituency and developing products that will interest it. The success of green power depends on taking a quintessential commodity, a kilowatt-hour, and differentiating it by how it is created.

\section{Differentiation, private benefits, and the common good}

By leveraging the literature on environmental differentiation in consumer markets, we can trace out the link between deregulation and the provision of public goods. Compared to conventional products, environmental differentiation consists of offering products that provide greater environmental benefits, or that impose smaller environmental costs. These products may be costlier than those traditional products, but they allow the firm to command a price premium in the marketplace or to capture additional market share. The environmental differentiation literature argues that one way of creating willingness to pay for public goods is to bundle them with private goods (Reinhardt, 1998). For example, many consumers are willing to pay a premium for organic food products that benefit directly their health and may taste better than nonorganic products. Speaking of Toyota's entry in the hybrid automobile market, an industry observer opined that 'if you want to wear your green credentials on your sleeve, the Prius is the way to go' (Ulrich, 2004). Thus, the Prius produces a private benefit to the wearer as others see his or her proenvironmental behavior. Green electricity does not offer private benefits - other than the warm glow of altruism-because green and brown electricity are identical once they reach the consumer, and because the product's use is within the household of the consumer.

How can such a lack of private benefits be overcome? One way is to use the public policy process to create the benefit. Consider first how this is playing out in the case of sustainably harvested lumber. Like electricity, lumber represents a case where it is difficult to bundle private and public goods: green lumber does not have physical characteristics that differ from brown lumber. It is therefore hard to imagine that mainstream customers will be willing to buy green lumber certified by the Forest Stewardship Council (FSC) at a 10-20 percent premium. At this point, policy-driven government purchases of green building materials still constitute most of the demand for FSC certified lumber. But as sales volumes rise the supply chain for FSC lumber will mature. Provided that additional sellers of FSC certified lumber are drawn to the marketplace, the price of FSC lumber will become competitive with non-FSC lumber, delivering private benefits.

A similar mechanism could occur in the electricity market. Green consumers still represent the minority of consumers, and change may come from recent public policies calling for requirements of minimums of green energy consumption by state-owned facilities. In the short term the effect of such mandates may be to increase the cost of green power via growth in demand. But if over the longer term these purchases can bring the costs of green power to competitive levels, broadened demand will energize scale economies and learning curve effects for manufacturers. In this way, demand for green power will expand and private benefits will appear. But this process is quite circuitous, compared to the more straightforward provision of private benefits seen in organic produce and other consumer product markets, where the private benefit is obvious and relatively immediate.

We have extended knowledge in the area of environmental differentiation with our analysis. Environmental differentiation plays out in ways that blend together traditional differentiation strategies with an element of conscious contribution to the common good that is not generally seen in the more familiar product differentiation that consumers face. It should be borne in mind that the study of this phenomenon is broader than the environmental context. For example, many social issues create platforms for differentiation in analogous ways, as when consumers take into account labor practices of companies when making purchasing decisions. Our knowledge of these points of 'social differentiation' - strategies used to create and exploit them, and the relative longevity of advantages they may create-is minimal. With information about the companies that make their products increasingly available and relevant to consumers, social differentiation also may become an important marketplace trend. Though researchers face a gap in the literature on this topic, that gap translates into a sizeable opportunity to 
study a phenomenon fueled by a growing momentum.

\section{ACKNOWLEDGEMENTS}

The authors acknowledge financial support from the following two sources: University of California Energy Institute grant \#SB040035, 'Governance and emissions performance in the electric generation industry'; and U.S. Environmental Protection Agency Star Program grant \#GR829687-01-0, 'Environmental Management Strategies and Corporate Performance: Identification and analysis of the motivators of regulated entities' environmental behavior and performance.' The authors are thankful to seminar participants at INSEAD, London Business School, University of Vermont, Arizona State University, the 2004 INFORMS Fall Conference, the 2005 Business and its Social Environment Conference and the 2005 Academy of Management Conference. Special thanks also are due to anonymous reviewers. Finally, the authors also thank Catherine Maritan, David Bach, Andrew King, and Michael Toffel for detailed comments on previous drafts.

\section{REFERENCES}

Alexander DL. 1992. Motor carrier deregulation and highway safety: an empirical analysis. Southern Economic Journal 59(1): 28-38.

Ando AW, Palmer KL. 1998. Getting on the map: the political economy of state-level electricity restructuring. Discussion paper 98-19-rev. Resources for the Future: Washington, DC.

Averch H, Johnson L. 1962. Behavior of the firm under regulatory constraint. American Economic Review 52: 1052-1069.

Banker R, Charnes A, Cooper WW. 1984. Some models for estimating technical and scale inefficiencies in data envelopment analysis. Management Science 30(9): 1078-1092.

Barney J. 1991. Firm resources and sustained competitive advantage. Journal of Management 17: 99-120.

Berry DM, Mixon FG Jr. 1999. Multiproduct outputs and scale economies in electric power production: some new estimates. Review of Industrial Organization 15: 65-76.

Bird L, Swezey B. 2003. Green Power Marketing in the United States (6th edn). National Renewable Energy Laboratory: Golden, CO.

Bird L, Swezey B, Aabakken J. 2004. Utility Green Pricing Programs: Design, Implementation, and Consumer Response. National Renewable Energy Laboratory: Golden, CO.
Bonardi JP. 1999. Market and nonmarket strategies of a former monopoly during deregulation: the British Telecom case. Business and Politics 1(2): 203-232.

Bonardi JP. 2004. Global and political strategies in deregulated industries: the asymmetric behaviors of former monopolies. Strategic Management Journal 25(2): $101-120$.

Brennan TJ, Palmer K, Martinez S. 2002. Implementing electricity restructuring: policies, potholes, and prospects. Environmental and Resource Economics 22: 99-132.

Breusch T, Pagan A. 1980. The Lagrange Multiplier test and its applications to model specification in econometrics. Review of Economics Studies 47: 239-253.

Burtraw D, Palmer K, Heintzelman M. 2000. Electric restructuring: consequences and opportunities for the environment. Discussion paper, Resources for the Future: Washington, DC.

Byrnes B, Jones C, Goodman S. 1999. Contingent valuation and real economic commitments: evidence from electric utility green pricing programs. Journal of Environmental Planning and Management 42(2): $149-157$.

Charnes A, Cooper WW, Rhodes E. 1978. Measuring the efficiency of decision making units. European Journal of Operational Research 2(6): 429-444.

Cho TS, Hambrick DC. 2006. Attention as the mediator between top management team characteristis and strategic change: the case of airline deregulation. Organization Science 17(4): 453-469.

Coelli TJ. 1996. A Guide to DEAP Version 2.1: A Data Envelopment Analysis Computer Program. Department of Econometrics. University of New England: Armidale, NSW, Australia.

Coelli TJ, Rao SP, Battese GE. 1998. An Introduction to Efficiency and Productivity Analysis. Kluwer: Boston, MA.

Cook RD, Weisberg S. 1983. Diagnostic for heteroscedasticity in regression. Biometrika 70: 1-10.

Corsi TM, Grimm CM, Smith KG, Smith RD. 1991. Deregulation, strategic change, and firm performance among LTL motor carriers. Transportation Journal 31(1): 4-14.

Costello K. 1995. The next Gordian Knot for state regulators and electric utilities: the unbundling of retail services. Electricity Journal 8(9): 38-49.

Delmas M, Tokat Y. 2005. Deregulation, efficiency and governance structures: the U.S. electric utility sector. Strategic Management Journal 26(5): 441-460.

Farhar B. 1999. Willingness to Pay for Electricity from Renewable Resources: A Review of Utility Market Research. National Renewable Energy Laboratory: Golden, CO.

Farrell MJ. 1957. The measurement of productive efficiency. Journal of the Royal Statistical Society Series A-General 120(3): 253-290.

Fox-Wolfgramm SJ, Boal KB, Hunt JG. 1998. Organizational adaptation to institutional change: a comparative study of first-order change in prospector and defender banks. Administrative Science Quarterly 43(1): $87-126$. 
Fuentelsaz L, Gomez J, Polo Y. 2002. Followers' entry timing: evidence from the Spanish banking sector after deregulation. Strategic Management Journal 23(3): 245-264.

Gormley ETJ. 1983. The Politics of Public Utility Regulation. University of Pittsburgh Press: Pittsburgh, PA.

Gray WB. 1997. Manufacturing plant location: does state pollution regulation matter? Working Paper 5880, National Bureau of Economic Research: Cambridge, MA.

Hamel G, Prahalad CK. 1989. Strategic Intent. Harvard Business Review 67(3): 63-76.

Haveman HA. 1992. Between a rock and a hard place: organizational change and performance under conditions of fundamental environmental transformation. Administrative Science Quarterly 37(1): 48-75.

Haveman HA. 1993. Organizational size and change: diversification in the savings and loan industry after deregulation. Administrative Science Quarterly 38(1): $20-51$.

Haveman HA, Russo MV, Meyer AD. 2001. Organizational environments in flux: the impact of regulatory punctuations on organizational domains, CEO succession, and performance. Organization Science 12(3): 253-273.

Interstate Renewable Energy Council (IREC). 2004. U.S. National Database of State Incentives for Renewable Energy (DSIRE). Interstate Renewable Energy Council. http://www.dsireusa.org/ [3 August 2005].

Joskow PL. 1997. Restructuring, competition and regulatory reform in the U.S. electricity sector. Journal of Economic Perspectives 11(3): 119-139.

Kahn ME. 2002. Demographic change and the demand for environmental regulation. Journal of Policy Analysis and Management 21(1): 45-62.

King A, Lenox M. 2000. Industry self-regulation without sanction: the chemical industry's Responsible Care Program. Academy of Management Journal 43(4): $698-716$.

Kassinis G, Vafeas N. 2002. Corporate boards and outside stakeholders as determinants of environmental litigation. Strategic Management Journal 23(5): $399-415$.

League of Conservation Voters. 1998-1999. National Environmental Scorecard. League of Conservation Voters: Washington, DC.

Levinson A. 1999. An industry-adjusted index of state environmental compliance cost. Working paper 7297, National Bureau of Economic Research: Cambridge, MA.

Majumdar S. 1998. On the utilization of resources: perspectives from the U.S. telecommunications industry. Strategic Management Journal 19(9): 809-831.

Majumdar SK, Marcus AA. 2001. Rules versus discretion: the productivity consequences of flexible regulations. Academy of Management Journal 44(1): $170-179$.

Meyer AD, Brooks GR, Goes JB. 1990. Environmental jolts and industry revolutions: organizational responses to discontinuous change. Strategic Management Journal 11(1): 93-110.

Miller D, Chen MJ. 1994. Sources and consequences of competitive inertia: a study of the U.S. airline industry. Administrative Science Quarterly 39(1): 1-23.

Odell AM. 2001. Watchdog challenges Southern Company. Posted 6 July on SocialFunds.com. http://www. socialfunds.com/news/print.cgi?sfArticleId=620. html [28 April 2006].

Ottman JA. 1998. Green Marketing: Opportunity for Innovation. NTC-McGraw-Hill: New York.

Porter M. 1985. Competitive Advantage: Creating and Sustaining Superior Performance. Free Press: New York.

Portland General Electric Company. 2004. Renewable power choices for your home. http://www.portlandgeneral.com//home/products/renewable_power/ default.asp. [1August 2004].

Reinhardt FL. 1998. Environmental product differentiation: implications for corporate strategy. California Management Review 40(4): 43-73.

Roberts MJ. 1986. Economies of density and size in the production and delivery of electric power. Land Economics 62(4): 378-387.

Rose NL. 1992. Fear of Flying? Economic analyses of airline safety. Journal of Economic Perspectives 6(2): 75-94.

Russo MV. 2001. Institutions, exchange relations, and the emergence of new fields: regulatory policies and independent power producing in America, 1978-1992. Administrative Science Quarterly 46(1): $57-86$.

Sawin J. 2003. Charting a new energy future. In In State of the World 2003, Starke L (ed), Norton: New York; 85-109.

Schneider National. 2005. Home page: http://www. schneider.com [1 August 2005].

Serchuk AH, Hirsh RF. 1998. Condemned to repeat? IOUs, history, and green markets. Electricity Journal 11(2): 76-86.

Shapiro DL, Rynes SL (eds). 2005. Editor's forum on the role of management scholarship in the public sector. Academy of Management Journal 48(6): 925-998.

Shepherd WG. 1985. Public Policies Toward Business ( 7 th edn). Irwin: Homewood, IL.

Smith GK, Grimm CM. 1987. Environmental variation, strategic change and firm performance: a study of railroad deregulation. Strategic Management Journal 8(4): 363-376.

StataCorp. 1999. Stata User's Guide. Stata Corporation: College Station, TX; 256-260.

Sweezy B, Houston AH, Porter KL. 1998. Green power takes off with choice in electricity. Public Utilities Fortnightly 136(15): 46-50.

Terry JC, Yandle B. 1997. EPA's toxic release inventory: stimulus and response. Managerial and Decision Economics 18(6): 433-411.

Thompson HG Jr. 1997. Cost efficiency in power procurement and delivery service in the electric utility industry. Land Economics 73(3): 287-296.

Tucker DJ. 1994. Problems and progress in population ecology. In Evolutionary Dynamics of Organizations, 
Baum JAC, Singh JV (eds). Oxford University Press: New York; 327-333.

Ulrich L. 2004. Interview on National Public Radio Morning Edition, 15 July 2004.

U.S. Census Bureau. 2000. Land area of states and other entities. U.S. Census Bureau: Washington, DC. http://www.census.gov/population/censusdata/90den stco.txt [28 April 2006].

U.S. Department of Energy. 1998-2000. FERC 1 Survey. Federal Energy Regulatory Commission: Washington, DC.

U.S. Department of Energy. 2000. The changing structure of the electric power industry: an update. Washington, DC.

U.S. Department of Energy. 2001. Status of state electric industry restructuring activity. http://www.eia.doe. gov/cneaf/electricity/chg_str/restructure.pdf [15 April 2002].

U.S. Department of Energy. 2004. Green power network: buying green power. http://www.eere.energy.gov/ greenpower/buying/index.shtml [3 August 2004].

U.S. Energy Information Administration. 1998. Challenges of electric power industry restructuring for fuel suppliers. Washington, DC.

U.S. Energy Information Administration. 1998-1999. Form EIA-861, annual electric power industry report. Washington, DC.

U.S. Environmental Protection Agency. 1999. Great Lakes binational toxics strategy: mercury utility subgroup meeting summary, 27 April.

U.S. Environmental Protection Agency. 1998-1999. Toxics release inventory: state fact sheets. Washington, DC.

U.S. Environmental Protection Agency. 2002. EGRID2002, Version 2.01. Washington, DC.

White H. 1980. Heteroscedasticity-consistent covariance matrix estimator and a direct test for heteroscedasticity. Econometrica, 48: 817-838.

Wholey DR, Sanchez SM. 1991. The effects of regulatory tools on organizational populations. Academy of Management Review 16: 743-767.

Winston C. 1998. U.S. industry adjustment to economic deregulation. Journal of Economic Perspectives 12(3): 89-110.

Wiser R, Bolinger M, Holt E, Swezey B. 2001. Forecasting the Growth of Green Power Markets in the United States. National Renewable Energy Laboratory: Golden, CO.

\section{APPENDIX: THE DATA ENVELOPMENT ANALYSIS TECHNIQUE}

The DEA technique uses linear programming to convert multiple input and output measures into a single measure of relative efficiency for each observation. A piecewise linear industry best practice frontier is constructed using the observations in the sample. If a firm is on this frontier, it is considered efficient. If it is not on the frontier, its radial distance from the best practice frontier is a measure of the firm's in efficiency. Majumdar (1998) presents a good overview of the DEA technique, while Coelli, Rao, and Battese (1998) provide a more detailed description. DEA is emerging as a powerful tool of data analysis for the electric utility sector as corroborated by the study of Majumdar and Marcus (2001), who used DEA in their paper on the impact of flexible environmental regulations on productivity in the electric utility sector.

Our construction of the measure of efficiency is derived from the work of Delmas and Tokat (2005), who analyzed the productivity consequences of deregulation regulations in the electric utility sector. Data came from FERC Form 1 reports. The efficiency of a firm in a specific year is computed by comparing it to all other firms in the same year, using a program written by Coelli (1996).

We use an input-oriented efficiency measure, which seeks to reduce the input without changing the output. Our DEA calculations also recognize that not all firms are operating at optimal scale. Therefore, we allow different firms to have different returns to scale and the efficiency measure is devoid of the scale effects (Coelli, 1996). The inputs and outputs of the variable that represents efficiency are described below.

\section{Inputs}

We use the following items as inputs: labor cost, plant value, production expenses, transmission expenses, distribution expenses, sales, administrative and general expenses, and electricity purchased from other sources in dollars. Our choice of inputs is consistent with the literature. Roberts (1986) suggests using electricity purchased from others, capital used in transmission and distribution in addition to generation inputs. Similarly, Majumdar and Marcus (2001) include production expenses, transmission expenses, distribution expenses, administrative and general expenses, number of employees as inputs to electric utilities, and electricity purchased from other sources.

\section{Outputs}

We consider the following outputs: low-voltage sales (residential and commercial), high-voltage 
sales (industrial), and sales for resale to other utilities. A firm's cost of supplying power to final consumers is affected by the type of customer it serves (Roberts, 1986; Thompson, 1997). High voltage sales incur less transmission costs than low voltage sales due to reduced operating and maintenance costs. Furthermore, wholesale sales are less costly than both low and high voltage sales, since they typically occur on less costly off-peak hours and entail larger quantities per transaction (Berry and Mixon, 1999). We consider these three types of outputs separately because of their differing costs. 